\title{
Potential of Rice Husk Ash as a Partial Cement Substitute in Rigid Highway Pavements
}

\author{
Fraser Hyndman ${ }^{1}$, Ash Ahmed ${ }^{1 *}$, John Kamau ${ }^{2}$ and Heni Fitriani ${ }^{3}$ \\ ${ }^{1}$ Department of Civil Engineering, UK
}

${ }^{2}$ Principal Engineer, Naylor Concrete Products, UK

${ }^{3}$ Department of Civil Engineering, Indonesia

*Corresponding author: Ash Ahmed, Department of Civil Engineering, England, UK

Submission: January 14, 2019; Published: January 23, 2019

\begin{abstract}
The highway pavement is the biggest structural asset a government can construct and maintain. Concrete rigid pavements are used to carry traffic in large volumes across countries safely and efficiently. The performance of the concrete pavement is vital for ensuring a successful economy. Pavement quality concrete mixes have high levels of portland cement which contributes to a large proportion of $\mathrm{CO}_{2}$ emissions in the UK and across the globe. Currently the UK specifies ground granulated blast furnace slag (GGBS) and pulverised fuel ash (PFA) to reduce the quantity of portland cement used in pavement construction. GGBS and PFA come from heavy industry; which are industries that should not be relied upon to improve the sustainability of construction materials. This report shows that cement in pavement quality concrete can be replaced with rice husk ash without causing adverse effects to the mechanical properties required for highways. Rice husk ash comes from the food production industry and is vital for the growing global population. It is seen that this is a socially responsible objective to use a pozzolan in highway pavement construction that is sourced from an environmentally friendly industry. The report investigates the resultant compressive and tensile strength of rice husk ash mixes and compares them to existing pavement quality mixes already used and specified. The report found that sieving rice husk ash and not grinding it gives the best performance. Due to the low density of rice husk ash the investigation found that replacing cement by volume rather than weight provided the best results. The investigation found that CEM II / A-LL 32,5N mixed with $20 \%$ rice husk ash meets the required specification for pavement quality concrete and mitigates using the comparative CEM I 52,5N mix. The investigation also notes that rice husk ash is observed to be more reactive with CEM II / A-LL 32,5N rather than CEM I 52,5N and suits early strength gains required for pavement construction. The report concludes that rice husk ash is a sustainable material that reduces the embodied $\mathrm{CO}_{2}$ of pavement quality concrete, which is well suited for building motorways to UK highway specifications and has the potential to improve the lives of people living in communities in rice growing countries across the globe.
\end{abstract}

Keywords: Rice husk ash; Pavement quality concrete; Pavement; Compressive strength

\section{Introduction}

The highway pavement is the biggest structural asset a country can build and operate. To construct rigid highway pavements involves using high quantities of portland cement. Rigid pavements demand high target cement content and a good degree of particle packing due to the aggressive environment it will be subjected to. The need to reduce the of portland cement in rigid pavements in now accepted by most governments with sustainability being key in most civil engineering contracts. It is reported in literature that apart from environmental friendliness, the use of supplementary cementitious materials (SCMs) such as pulverised fuel ash (PFA), ground granulated blast furnace slag (GGBS), Silica fume (SF) and rice husk ash (RHA) reduces the cost of concrete and improves the durability of hardened concrete, thereby enhancing the service life of structures [1,2]. This report undertakes an investigation into the use of rice husk ash as a pozzolan in rigid pavements to reduce the portland cement content required to achieve British highway specifications.
Cement is deemed to have a considerably high carbon footprint, contributing immensely to global anthropogenic $\mathrm{CO}_{2}$ [3]. Global warming is a phenomenon that brings about a rise in global temperatures due to the presence of excessive carbon dioxide $\left(\mathrm{CO}_{2}\right)$ in the atmosphere and is cumulative and irreversible over timescales of centuries $[4,5]$. The burning of fossil fuels, in this case to produce cement contributes to the greenhouse gas effect, which is a major cause of global warming [6]. Even though heavily energy intensive, cement is pivotal to development and is produced in virtually all countries [7]. One ton of concrete on average is produced every year for each human being in the world, a population that currently stands above 7 billion [8]. The growing population, matched by a corresponding increase in demand for socio-economic infrastructure that is aimed at creating affluent societies, especially in the developing world and former socialite countries [9], has led to a gradual increase in the demand for cement in the past few decades, with construction investment directly 
linked to higher gross domestic product (GDP) $[10,11]$. Cement was described by Al-Salami [12] as the most utilised construction material in the world, its global consumption only seconding that of water. It constitutes between $7 \%-15 \%$ of the total mass of concrete mixes [13], yet according to Sakai [11], the development of a nation is directly proportional to its consumption of concrete. Its yearly global production was 1.6 billion tons over 10 years ago, accounting for about $7 \%$ of the total global $\mathrm{CO}_{2}$ loading in the atmosphere, a considerably high level of emissions when compared to $2 \%$ total global $\mathrm{CO}_{2}$ emissions attributed to the aviation industry [14-16].

SCMs comprising industrial and agricultural waste products such as PFA, GGBS, SF, RHA and CCA unnecessarily occupy space when stored or create environmental hazards when dumped in landfill [1]. Their utilisation in the construction industry reduces the overall cost of construction, mitigates on the technical and environmental nuisance that is associated with the production of cement, reduces solid waste, cuts on greenhouse gas emissions and conserves existing natural resources, thereby enhancing sustainability as well as improving the properties of fresh and hardened concrete [17-21].

The production of a ton of cement emits approximately a corresponding ton of $\mathrm{CO}_{2}$ [17], making it the most energy-intensive material produced after steel and aluminium $[3,14]$. In as much as development is required to match increasing populations, it should also be sustainable [18]. The underlying principles of sustainability lie in the appropriate balance of economic, social and environmental impacts [19]. Steel et al. [18] defined sustainability as a road for society advancement in which progress must be in harmony with the natural world, rather than in conflict with it, while Gambhir [14], termed it as a regime in which endeavors are towards meeting the needs of the present generation without compromising those of future generations. With a heavy demand for concrete in the developing world and other major and equally populous economies such as China and India predicted, cement producing companies have not anticipated in the foreseeable future any major changes in production that will reduce on emissions [1]. However, energy efficiency can be achieved by reducing on the amount of clinker and

Table 1: Specimen mixes prepared. utilizing SCMs, which require less process heating and emit fewer levels of $\mathrm{CO}_{2}$ [14]

The report compares mechanical properties and workability of concrete mixes prepared to British highway specification [22,23]. The investigation looks at the minimum processing of the rice husk ash required to achieve the acceptable strength properties and compares. The investigation prepared GGBS and OPC mixes to the same specification for comparison. The fines and aggregate used in this study are been chosen as they are sourced from locations other than open cast mining. Table 1 shows mixes investigated, the mix ratio is referenced is: cement: fine aggregate: coarse aggregate.

\section{Experimental}

Work was undertaken to investigate the mechanical and workability properties of the mixes shown in Table 1 . The mixes have been selected to show the differing quality of materials available and the impact this has on the properties of the fresh and hardened concrete. The rice husk ash was received unprocessed with organic matter still present in the ash; much like what that would be received from rice plantations. The rice husk ash was prepared in two states; first of which being sieved through a 500 -micron sieve, which was recorded as having a density of 0.21 of portland cement; and secondly being sieved through a 500-micron sieve, ground in a ball mill and sieved through a 45-micron sieve, which was recorded as having a density of 0.42 of portland cement. As the volume of the ash is significantly different to ordinary Portland cement the proportionality of replacement was modified to account for this difference. CEM I 52,5N, white cement, and CEM II / A-LL 32,5N were used to evaluate the use of high-quality cement with pozzolanic material. Each mix was evaluated for workability and the common slump tests to were undertaken. This test reports the suitability for different types of pavement construction whether being poured or using slip form construction. The minimum requirement of mechanical properties specified in the MCHW [22,23] has been investigated through compression, tensile and density testing of cubes and cylinders at 1, 7 and 28 days. All preparation and testing were conducted in accordance to the relevant European British standards - [24-29].

\begin{tabular}{|c|c|c|c|}
\hline Reference & Cement Material & Cement Replacement Proportion & Mix Ratio \\
\hline Control & CEM I 52,5N (White portland cement) & $0 \%$ & $1: 1: 3$ \\
\hline 20 RHA & CEM I 52,5 N / SIEVED RHA & $20 \%$ By Volume & $1: 1: 3$ \\
\hline 40 RHA & CEM I 52,5N / SIEVED RHA & $40 \%$ By Volume & $1: 1: 3$ \\
\hline 80 RHA & CEM I 52,5N / SIEVED RHA & $80 \%$ By Volume & $1: 1: 3$ \\
\hline 20 RHAG & CEM I 52,5N / SIEVED \& GROUND RHA & $20 \%$ By Volume \\
\hline 200 PCRHAG & CEM II / A-LL 32,5N / SIEVED \& GROUND RHA & $20 \%$ By Volume & $1: 1: 3$ \\
\hline $20 G G B S$ & CEM I 52,5N / GGBS & $20 \%$ By mass & $1: 1: 3$ \\
\hline $40 G G B S$ & CEM I 52,5N / GGBS & $40 \%$ By mass \\
\hline $80 G G B S$ & CEM I 52,5N / GGBS & $80 \%$ By mass & $1: 1: 3$ \\
\hline
\end{tabular}


The report uses the experiments to evaluate the applicability of replacing cement with rice husk ash to make a pavement quality concrete that satisfies British highway pavement standards and specification.

\section{Test materials}

Cement: The cement used was white Portland cement designation CEM I 52,5N to BS EN 197: Part 1 [24], and portlandlimestone cement CEM II/A-LL 32,5N to BS EN 197: Part 1[24].

Rice husk ash: The rice husk ash has been sourced from the far east. The chemical composition of the ash is detailed in the report and shows the ash to contain a high content of amorphous silica content and a residual amount of carbon.

Ground granulated blast-furnace slag: Ground granulated blast-furnace slag sourced from tata steel in scunthorpe to classification BS EN 15167-Part 1.

Sand: Sharp sand was used complying with BS 1200 [30].

Aggregate: $20 \mathrm{~mm}$ siliceous gravel (local river bottom) conforming to BS EN 12620 [31].

Water: Water used conforming to EN 1008 [32].

\section{Specimen preparation}

Rice husk ash preparation: A sample of rice husk ash was tested for chemical composition through XRD. The chemical composition of the RHA is detailed in Table 2 . The sample was oven dried at 110 degrees centigrade for 24 hours to remove moisture and speed up processing time. The ash was sieved through a 500-micron sieve to remove any residual husks, foreign objects and other organic matter. This is referred to as RHA1. A sample was taken at this point and mixes prepared as shown in Table 1. The remaining rice husk ash was then ground in a ball mill for 15 minutes. The ash was then passed through a 45-micron sieve. This is referred to as RHA2.

Table 2: Compressive strength results-28 day.

\begin{tabular}{|c|c|c|}
\hline $\begin{array}{c}\text { Reference } \\
\text { (Table 1) }\end{array}$ & $\begin{array}{c}\text { Age } \\
\text { (Days) }\end{array}$ & $\begin{array}{c}\text { Ave Compressive Strength } \\
\text { (N/mm } \mathbf{~}^{\text {) }}\end{array}$ \\
\hline Control & 28 & 40.1 \\
\hline $20 \%$ RHA & 28 & 40.8 \\
\hline $\begin{array}{c}20 \% \text { RHAG } \\
\text { (ground RHA) }\end{array}$ & 28 & 39.8 \\
\hline $\begin{array}{c}20 \% \text { OPCRHAG } \\
\text { (CEM II, ground RHA) }\end{array}$ & 28 & 35.7 \\
\hline $20 \%$ GGBS & 28 & 46.9 \\
\hline $40 \%$ RHA & 28 & 30.8 \\
\hline $80 \%$ RHA & 28 & 8.10 \\
\hline
\end{tabular}

Compressive strength: Compressive strength was determined using $100 \times 100 \times 100 \mathrm{~mm}$ cubes using a mix ratio of 1:1:3 with a target equivalent cement content of $350 \mathrm{~kg} / \mathrm{m}^{3}$. Cement proportion has been calculated using volume as opposed by weight. Mixes were prepared as shown in Table $1 . \mathrm{W} / \mathrm{C}$ ratio used across all mixes was 0.45 , the maximum allowed for pavement quality concrete $[22,23]$. Samples where loaded into the moulds and placed on a vibrating table for compaction. The samples were allowed to set for 24 hours before being removed from the moulds. The cubes where labelled and placed in a water bath at a constant $20^{\circ} \mathrm{C}$ until testing. The cubes were tested by using an Avery-Denison testing machine at a loading rate of $200 \mathrm{~N} / \mathrm{min}$. Three cubes from each mix were tested at 1,7 and 28 days. The average load was recorded.

Tensile strength: The tensile strength was determined using cylinder specimens of $150 \mathrm{~mm}$ diameter and $300 \mathrm{~mm}$ height. Two cylinders were prepared from each mix detail in Table 1. Each cylindrical mould was loaded in three layers; each layer was tampered 25 times to ensure compaction. The samples were allowed to set for 24 hours before being removed from the moulds. The cylinders were labelled and placed in a water bath at a constant $20{ }^{\circ} \mathrm{C}$ until testing. The cylinders were loaded onto the jig and tested by using an Avery-Denison testing machine at a loading rate of $353 \mathrm{kN} / \mathrm{min}$. The two cylinders from each mix were tested at 28 days. The average load was recorded.

\section{Results and Discussion}

\section{Compressive strength}

Table 2

The minimum 28-day compressive cube strength requirement for highway pavements in the $\mathrm{UK}$ is $37 \mathrm{~N} / \mathrm{mm}^{2}$; this is the requirement for CEM I concrete mixes. There is an allowance for CEM I \& SCMs (containing either PFA or GGBS) mixes which equates to $82 \%$ of the compressive strength of CEM I concrete mixes - this is $30 \mathrm{~N} / \mathrm{mm}^{2}$ strength at 28 days - with the caveat that the mix will eventually meet the minimum compressive strength required as concrete containing partial cement replacements gain strength for up to 365 days, i.e. long term strength gain as substantiated by many researchers [2,16,33-35]. This means any concrete mix containing partial cement replacements must achieve a minimum compressive strength of $30 \mathrm{~N} / \mathrm{mm}^{2}$ by 28 days and $37 \mathrm{~N} / \mathrm{mm}^{2}$ by 91 days. Giving the same allowance to mixes containing RHA, with the exception of $80 \%$ RHA all other mixes exceed the requirements of the minimum compressive strength requirements for motorway standards. Further to this Figure 1 shows that both 20\% and 40\% RHA concrete mixes reached the minimum requirement of pavement quality concrete at 28 days. According to Bapat [1] \& Shetty [36], the early age strength for concrete containing PCRs is solely due to the hydration of cement, with the RHA only acting as an inert filler of voids and not substantially contributing to the strength gain, while the latter age strength was due to the reaction of $\mathrm{SiO}_{2}$ present in the RHA with free lime $\left[\mathrm{Ca}(\mathrm{OH})_{2}\right]$ from the hydration of cement in a secondary reaction over time, to form strength giving compounds such as calcium silicate hydrate (C-S-H). Quite interestingly, 20\% RHA with CEM II 32.5 has nearly the same strength as 20\% RHA with CEM I 52.5 which is very intriguing given the disparity in strength class between both sets of cements [37]. 


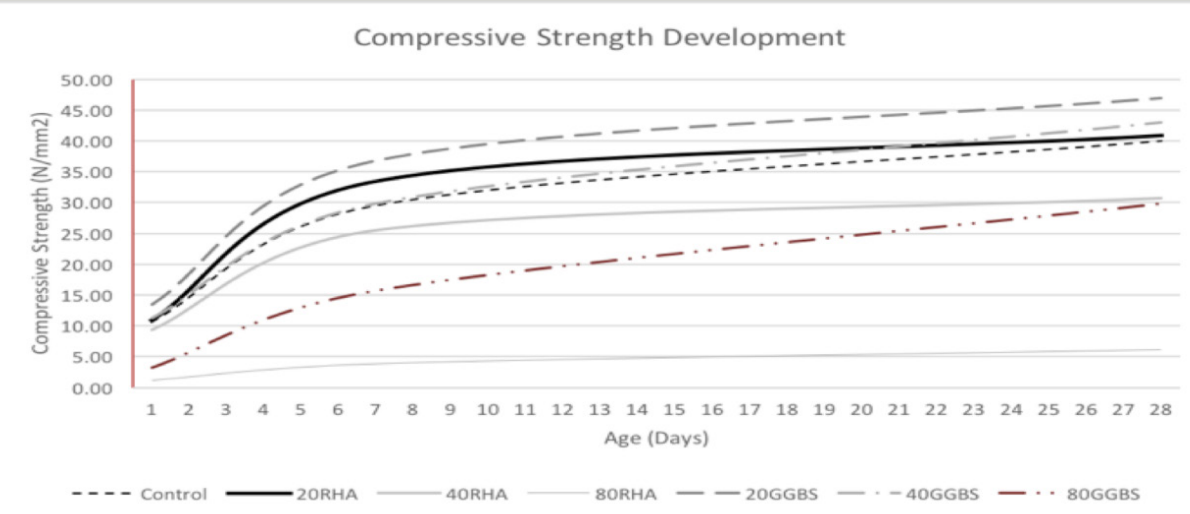

(a) Strength gain comparison between varying GGBS and RHA replacements.

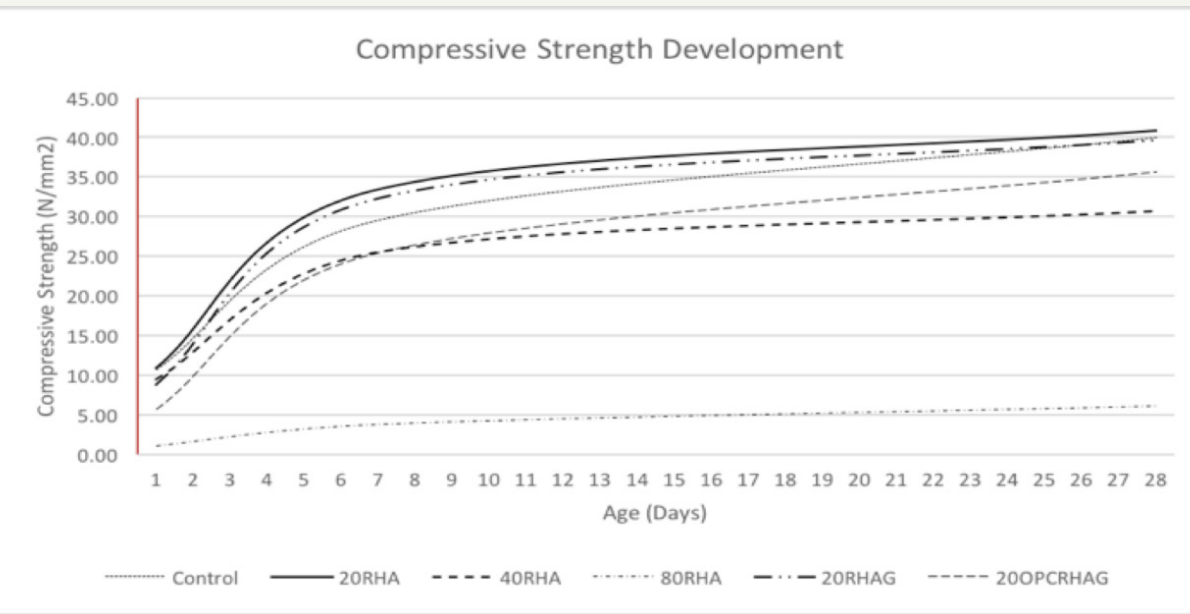

(b) Strength gain comparison between RHA mixes.

Figure 1: Compressive strength development.

The results also suggest that grinding the RHA lessens the reactivity of the material resulting in a marginally lower strength concrete. This concurs with work done by Mahta [38] who reports that the reactivity of the pozzolan is due to the internal surface area of the particles. It was also noticed that the workability of the unground RHA was significantly better which may be due to the pores retaining the water within the mix and therefore improving the hydration reaction; however, unlike GGBS and PFA, the addition of RHA does not increase the workability, in fact like silica fume, i.e., the water demand of concrete containing RHA increases with increasing amounts of RHA. This increase is likely to be caused by the high surface area of the RHA. On the other hand, the fresh concrete containing RHA was observed to be more cohesive and less prone to segregation than concrete containing 100\% CEM I.

\section{Tensile strength}

The tensile strength of pavement quality concrete is an important mechanical property when considering the most economical concrete mix to be used to construct continuously reinforced concrete pavements. The correct mix will ensure longevity of the pavement during service and improve the whole-time cost. Table 3 shows the indirect tensile strength of the mixes as detailed in Table 1. The results show that RHA mixes have a reduced tensile strength.
This is as reported by Sarawathy et al. [39]. Although these results may seem significant, the mixes reporting acceptable compressive strength for pavement quality concrete maintain an acceptable 28day tensile strength and therefore for the purposes of this report are not a concern $[40,41]$.

Table 3: Tensile strength results-28 day.

\begin{tabular}{|c|c|c|}
\hline $\begin{array}{l}\text { Reference } \\
\text { (Table 1) }\end{array}$ & $\begin{array}{c}\text { Age } \\
\text { (Days) }\end{array}$ & Average Tensile Strength $\left(\mathrm{N} / \mathrm{mm}^{2}\right)$ \\
\hline Control & 28 & 4.1 \\
\hline $20 \%$ RHA & 28 & 3.5 \\
\hline $\begin{array}{c}\text { 20\% RHAG } \\
\text { (ground RHA) }\end{array}$ & 28 & 3.7 \\
\hline $\begin{array}{c}20 \% \text { OPCRHAG } \\
\text { (CEM II, ground RHA) }\end{array}$ & 28 & 3.2 \\
\hline $20 \%$ GGBS & 28 & 4.1 \\
\hline $40 \%$ RHA & 28 & 2.7 \\
\hline $80 \%$ RHA & 28 & 1.9 \\
\hline
\end{tabular}




\section{Conclusion}

a) It is recommended that replacing cement with unground and sieved RHA up to $20 \%$ can provide an improved pavement quality concrete.

b) RHA/cement concrete mixes have higher water demand however are less prone to segregation.

c) It is recommended that RHA be sieved through a 500-micron sieve before using. Preferably RHA should not be ground.

d) The use of CEM II / A-LL 32,5N and 20\% replacement of RHA produces a pavement quality concrete sufficient enough for motorway roads.

e) CEM II / A-LL 32,5N and 20\% replacement of RHA increases improves the compressive and tensile strength of pavement concrete.

f) The use of CEM I 52,5N and 20\% replacement with RHA produces a pavement quality concrete applicable to motorway networks in the UK.

\section{Acknowledgement}

The authors would like to express their gratitude to the British Council (UK and Indonesia) for funding of this project.

\section{References}

1. Bapat JD (2012) Mineral admixtures in cement and concrete. CRC Press, Florida, USA.

2. Mohammed OH, Hamid RB, Taha MR (2012) A review of sustainable supplementary cementitious materials as an alternative to all-portland cement mortar and concrete. Australian Journal of Basic \& Applied Sciences 6(9): 287-303.

3. Brien EJO, Dixon AS, Sheils E (2012) Reinforced and prestressed concrete design to EC2: The complete process. Spon Press, London, UK.

4. Akinboboye F, Ogunfayo I, Dawodu H (2012) Assessment of the severity of $\mathrm{CO}_{2}$ emission from anthill soils used as replacement for shale in cement manufacture. International Journal of Academic Research in Business and Social Sciences 2(12): 145-149.

5. Cline WR (1992) The economics of global warming. Peterson Institute, Washington DC, USA

6. Yerramala A, Desai B (2012) Influence of fly ash replacement on strength properties of cement mortar. International Journal of Engineering Science and Technology 4(8): 3657-3665.

7. Soyka MJGP, Conneely D. $\mathrm{CO}_{2}$ emissions from cement production. Good practice guidance and uncertainty management in national greenhouse gas inventories.

8. Lippiatt B, Ahmad S (2004) Measuring the life-cycle environmental and economic performance of concrete: the BEES approach. International Workshop on Sustainable Development and Concrete Technology, pp. 213-230.

9. http://www.worldometers.info/world-population/

10. Muga H, Betz K, Walker J, Pranger C, Vidor A, et al. (2005) Development of appropriate and sustainable construction materials. Civil and Environmental Engineering Sustainable Futures Institute, Michigan Technology University, Michigan, USA.

11. Sakai K, Noguchi T (2012) The sustainable use of concrete: CRC press, Florida, USA.
12. Al-Salami A, Salem A (2010) Effects of mix composition on the sulfate resistance of blended cements. International Journal of Civil \& Environmental Engineering 10(6): 37-41.

13. Islam M (2013) Strength and durability characteristics of concrete made with fly-ash blended cement. Australian Journal of Structural Engineering 14(3): 303-319.

14. Gambhir (2009) Concrete technology 4e. Tata McGraw-Hill Education, New York, USA.

15. Mehta PK (2001) Reducing the environmental impact of concrete. Concrete International 23: 61-66.

16. Johnson ME, Gonzalez A (2013) Estimating cost savings for aviation fuel and $\mathrm{CO}_{2}$ emission reductions strategies. Collegiate Aviation Review 31(2): 79-102.

17. Khan R, Jabbar A, Ahmad I, Khan W, Khan AN, et al. (2012) Reduction in environmental problems using rice-husk ash in concrete. Construction and Building Materials 30: 360-365.

18. Steele K, Cole G, Parke G, Clarke B, Harding J (2002) The application of life cycle assessment technique in the investigation of brick arch highway bridges. Engineering Doctorate in Environmental Technology.

19. Davison B, Owens GW (2011) Steel designers' manual.

20. Malhotra V, Mehta P (2005) High-performance, high-volume fly ash concrete: Materials, mixture proportions, properties, construction practice, and case histories. Supplementary Cementing Materials for Sustainable Development Inc., Ottawa, ON, Canada.

21. Sengul O, Tasdemir MA (2009) Compressive strength and rapid chloride permeability of concretes with ground fly ash and slag. Journal of Materials in Civil Engineering 21: 494-501.

22. Highways England (2005) MCHW Vol 1 Series 1000 road pavementsconcrete materials.

23. Highways England (2006) DMRB Vol 7 Sec 2 Part 3 HD 26/06 pavement design.

24. (2000) BSI, BS EN 197-1: 2000. Part 1 Cement composition, specifications and conformity criteria for common cements. British Standards Institution (BSI), London, UK.

25. (2012) BSI, BS EN 12390-1:2012. Testing hardened concrete. Part 1: Shape, dimensions and other requirements for specimens and moulds. British Standards Institution (BSI), London, UK.

26. (2009) BSI, BS EN 12390-2:2009. Making and curing specimens for strength tests. British Standards Institution (BSI), London, UK.

27.(2000) BSI, BS EN 12390-4:2000. Testing hardened concrete. Compressive strength. Specification for testing machines. British Standards Institution (BSI), London, UK.

28. (2004) BSI, BS EN 1992-1-1: 2004: Eurocode 2: Design of concrete structures, Part 1-1: General rules and rules for buildings. British Standards Institution (BSI), London, UK.

29. (2015) BSI, BS 8500-1:2015: Concrete-complementary British standard to BS EN 206. Part 1: Method of specifying and guidance for the specifier British Standards Institution (BSI), London, UK.

30. (1976) BSI, BS 1199 and 1200 (1976). Specifications for building sands from Natural resources. British Standards Institution (BSI), London, UK.

31. (2013) BSI, BS EN 12620:2013. Aggregates for concrete. British Standards Institution (BSI), London, UK.

32. (2002) BSI, BS EN 1008:2002. Mixing water for concrete. Specification for sampling, testing and assessing the suitability of water, including water recovered from processes in the concrete industry, as mixing water for concrete. British Standards Institution (BSI), London, UK.

33. Gambhir, Murari L (2009) Concrete technology 4e. Tata McGraw-Hill Education, New York, USA. 
34. Kamau, John, Ash A, Paul H, Joseph K (2016) Suitability of corncob ash as a supplementary cementitious material. International Journal of Materials Science and Engineering 4(4): 215-228.

35. Kamau, John, Ash A, Paul H, Joseph K (2017) Suitability of anthil soil as a supplementary cementitious material.

36. Shetty M (2005) Concrete technology: theory and practice.

37. Chand S, Olafusi O, Olutoge F (2012) Strength properties of corn cob ash concrete. Journal of Emerging Trends in Engineering and Applied Sciences 3: 297-301.

38. Mahta PK (1979) The Chemistry and technology of cement made from Rich Husk Ash. In: Proceedings UNIDO/ESCAP/RCTT Workshop on Rich Husk Ash Cements. Peshawar, Pakistan.
39. Saraswathy V (2006) Corrosion performance of Rice Husk Ash blended concrete. In Construction and Building Materials 21(2007): 1779-1784. Elsevier, Republic of Korea.

40. Adesanya DA, Raheem AA (2009) A study of the workability and compressive strength characteristics of corn cob ash blended cement concrete. Construction and Building Materials 23(1): 311-317.

41. Adesanya D (1996) Evaluation of blended cement mortar, concrete and stabilized earth made from ordinary Portland cement and corn cob ash. Construction and Building Materials 10(6): 451-456.

For possible submissions Click Here

Submit Article 